\title{
Effects of Warm Water Intrusions on Populations of Macrozooplankton on Georges Bank, Northwest Atlantic
}

\section{Harmon Brown ${ }^{1^{*}}$, Stephen M. Bollens ${ }^{1^{* *}}$ \\ Laurence P. Madin ${ }^{2}$ and Erich F. Horgan ${ }^{2}$}

${ }^{1}$ Romberg Tiburon Center for Environmental Studies and Department of Biology, San Francisco State University, 3152 Paradise Drive, Tiburon, CA, 94920, USA

${ }^{2}$ Biology Department, Woods Hole Oceanographic Institution, Woods Hole, MA 02543, USA

*Corresponding author: Current address: Coastal Fisheries Institute, Department of Oceanography and Coastal Sciences, Louisiana State University, Baton Rouge, LA, 70803, USA

** Current address: School of Biological Sciences, Washington State University Vancouver, 4204 NE Salmon Creek Avenue, Vancouver, WA, 98686, USA

Submitted in revised form to Continental Shelf Research, June 21, 2004 


\begin{abstract}
As part of the Georges Bank/North West Atlantic GLOBEC (Global Ocean Ecosystems Dynamics) Program, macrozooplankton and micronekton were collected on 30

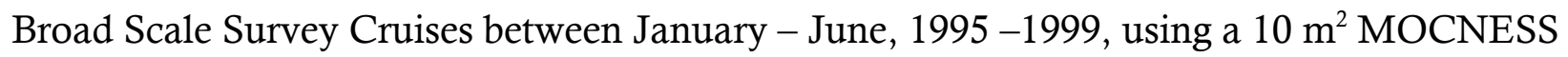
( $3 \mathrm{~mm}$ mesh). The objective of this study is to examine the effects of warm water intrusions on populations of macrozooplankton, namely Salpa spp., Phronima spp., Neomysis americana, and Crangon septemspinosa, on Georges Bank. Salpa spp. and Phronima spp. showed a large degree of horizontal co-occurrence, being found predominantly in Upper Slope/Gulf Stream Water and Georges Bank/Gulf of Maine Water. Abundances of these taxa showed striking interannual variability, and were only abundant on the southern flank and in the Northeast Channel in late spring/early summer of 1995 and 1999, periods during which AVHRR imagery and hydrographic data showed the presence of warm water intrusions. These intrusions seemed to have little effect on the distribution of other macrozooplankton (e.g., Neomysis americana and Crangon septemspinosa). Warm water intrusions can directly affect Salpa spp. and Phronima spp. populations by advecting them onto Georges Bank, although other, more resident populations, especially those inside the $100 \mathrm{~m}$ isobath, seem to be little affected by such intrusions.
\end{abstract}

\title{
Keywords
}

Macrozooplankton; distribution; abundance; warm water intrusions; slope water; Northwest Atlantic; Georges Bank 


\section{Introduction}

Georges Bank is a submarine bank that lies between Cape Cod, Massachusetts and Cape Sable, Nova Scotia in the Northwest Atlantic. It is one of the most productive seamount ecosystems in the world (Cohen and Grosslein, 1987) and the site of important commercial fisheries (Bigelow, 1926; Backus and Bourne, 1987). The Global Ocean Ecosystems Dynamics (GLOBEC) Georges Bank Program is charged with investigating the physical and biological oceanographic processes that affect four target species: the copepods Calanus finmarchicus, Pseudocalanus spp. and the larval stages of cod (Gadus morhua) and haddock (Melanogrammus aeglifinus) (GLOBEC, 1992). As part of the GLOBEC BroadScale Survey sampling, the macrozooplankton and micronekton of Georges Bank were sampled in January-June 1995-1999. Although designed to target juvenile fishes and predators of the GLOBEC target species, these collections included many thousands of specimens of the pelagic tunicate Salpa spp., the hyperid amphipod Phronima spp., the decapod shrimp Crangon septemspinosa, and the mysid shrimp Neomysis americana, which will be the focus of this paper.

Intrusion of slope water onto the southern flank of the bank can be caused by Gulf Stream meander crests that pinch off to form warm core rings (Ryan et al., 2001). Cornillon et al. (1994) estimated that approximately 8 warm core rings are seen in the Northwest Atlantic each year, although few of these rings move beyond the $200 \mathrm{~m}$ isobath onto the southern flank of Georges Bank. These intrusions can have important biological consequences, including impacts on phytoplankton (Flierl and Davis, 1993), copepods (Ashjian et al., 2001) and larval fishes (Wroblewski and Cheney, 1984; Flierl and 
Wroblewski, 1985). However, the effects of these slope water intrusions on the ecology of macrozooplankton and micronekton of Georges Bank have not previously been reported.

The objective of this study is to examine the effects of warm water intrusions on the distribution and abundance of populations of Salpa spp., Phronima spp., Crangon septemspinosa, and Neomysis americana, on Georges Bank. These 4 taxa were chosen because of their contrasting patterns of occurrence on the bank. Salpa spp. and Phronima spp. are only rarely present, but can occasionally achieve very high abundances, whereas Crangon septemspinosa and Neomysis americana are far more common on the bank, especially inside then $100 \mathrm{~m}$ isobath (Whiteley 1948).

\section{Study Site}

Georges Bank, defined by the $200 \mathrm{~m}$ isobath (Figure 1), is approximately $150 \mathrm{~km}$ wide and $280 \mathrm{~km}$ long, and shoals to as little as $30 \mathrm{~m}$. The dominant circulation pattern is one of a permanent anticylonic gyre around the bank (Limeburner and Beardsley, 1996). Butman and Beardsley (1987) divide the bank region into four physical regions based on water properties and the spatial structure of the currents - the northern flank $(50-200 \mathrm{~m})$; the bank crest $(\leq 60 \mathrm{~m})$; the shallower southern flank $(60-150 \mathrm{~m})$; and the deeper southern flank $(>150 \mathrm{~m})$ on the northern side of the shelf-water/slope-water front, which can be strongly influenced by warm-core rings. There is a relatively constant flow of upper Slope Water in the Northeastern Channel below 100m (Ramp et al., 1985). 


\section{Methods}

The Georges Bank region was sampled monthly during the period of February July, 1995 and January - June, 1996 - 1999 as a part of the GLOBEC Georges Bank Broad Scale Surveys. A cruise track consisting of ca. 40 sampling stations was occupied each month (Figure 1; http://globec.whoi.edu). Sampling of macrozooplankton and micronekton was undertaken at as many stations as possible on each cruise, allowing for problems with weather and equipment (Table 1).

A $10 \mathrm{~m}^{2}$ Multiple Opening/Closing Net and Environmental Sampling System (MOC10) (Wiebe et al., 1985b) was used for sampling. The MOC10 consists of a $10 \mathrm{~m}^{2}$ frame and five $3 \mathrm{~mm}$ mesh nets. The MOC10 allows for sampling in discrete depth strata by opening and closing the nets remotely from the ship. The MOC10 was towed in a double oblique manner ( 1 net down, $\leq 4$ nets up) with a goal of sampling $5,000 \mathrm{~m}^{3}$ of water per net. The nets were opened and closed at predetermined depths (nominally, 100, 40, 15 and $0 \mathrm{~m}$ ) during the ascent of the tow. The MOC10 was also equipped with Conductivity, Temperature, and Depth (CTD) sensors. The overall survey design (e.g. stations, depths and seasons to be sampled) was intended to target juvenile fishes and invertebrate predators (GLOBEC, 1992), although, as will be seen below, many other macrozooplankton were also commonly collected.

Once on board, the nets were rinsed to remove all animals, and the contents of the cod ends were placed in jars and preserved in $5-10 \%$ formalin. The samples were analyzed in the laboratory and all specimens were identified to the lowest practicable taxon using taxonomic descriptions provided in Tattersall and Tattersall (1951), Gosner (1971), Bowman and Gruner (1973), and Williams (1984). Individuals within the genus Salpa were 
not identified to the species level nor as solitary or aggregate generation. Both Salpa aspera and Salpa fusiformis were found in the samples, but were grouped under the single category of Salpa spp. for the data set as a whole. Individuals within the genus Phronima were not identified to species. Shih (1969) stated that the geographic distributions of Phronima sedentaria and Phronima atlantica include the northwest Atlantic, and we therefore assume (but can not be certain) that both species were present in our collections. Crangon septemspinosa and Neomysis americana were identified to species. All individuals within each taxonomic group were enumerated and the first 50 individuals within each group were measured in length to the nearest millimeter. Damaged animals were enumerated, but not measured. After the samples were analyzed they were represerved in $5-10 \%$ formalin.

The presence of each species was plotted in Temperature-Salinity (T-S) space, using the average T-S values from each depth stratum sampled. The T-S space of three different water masses, Scotian Shelf Water (SSW), Georges Bank/Gulf of Maine Water (GBW) and Upper Slope/Gulf Stream Water (USW), were derived from Flagg (1987).

Sea surface temperatures (SST), derived from the National Oceanic and Atmospheric Administration Advanced Very High Resolution Radiometer (NOAA AVHRR) data, were analyzed using MATLAB $^{\circledR}$ to estimate the percent cover of slope water within the $200 \mathrm{~m}$ isobath of the Georges Bank region. Because each MOC10 survey occurred over a period of about two weeks, we selected AVHRR data from three consecutive dates in the middle of each cruise to provide a representative estimate of the amount of slope water cover. A warmest pixel composite was made from all available data for these three days from each cruise in order to improve data retrieval due to clouds or fog. Georges Bank was defined by the $200 \mathrm{~m}$ isobath, except for the northwest section where the $150 \mathrm{~m}$ isobath was used to 
bisect the Great South Channel. Percent cover of slope water was determined within that area by calculating the percent of data (pixels) that represented sea surface temperatures of $16^{\circ} \mathrm{C}$ (slope water lower threshold) or higher.

The software package Minitab ${ }^{\circledR} 12$ was used for all statistical analyses. MannWhitney U-tests (with Bonferroni Adjustment for multiple comparisons) were used to compare interannual abundances of each of the four species, and chi-square tests were used to test for differences in the presence/absence of each of the species between different water masses. Finally, the abundances of each species were tested for correlation (Pearson product moment) with the percent cover of slope water on the bank.

\section{Results}

From 1995-1999, thirty broad-scale cruises were undertaken to Georges Bank, and 465 tows were made with the MOC10, yielding 1,388 discrete samples. Over 1.3 million individuals were identified and enumerated, representing 426 distinct taxa. A complete discussion and analysis of this larger dataset will be reported elsewhere. In this paper we report only on Neomysis americana, Salpa spp., Crangon septemspinosa, and Phronima spp., the $2^{\text {nd }}, 3^{\text {rd }}, 8^{\text {th }}$ and $22^{\text {nd }}$ most abundant taxa, respectively, which collectively comprised 291,110 specimens, or about $21 \%$ of the total number of organisms sampled. The mean total water column abundances, standard errors, and maximum total water column abundances are shown in Table 2.

The seasonal and interannual abundances of each of these species can be seen in Figure 2. While Salpa spp. and Phronima spp. are virtually absent in 1996, 1997 and 1998, they occur in high numbers in both 1995 and 1999. Mann-Whitney U-tests (with 
Bonferroni Adjustment for multiple comparisons) were performed to compare the interannual abundances of each of the four taxa (Table 3). For both Salpa spp. and Phronima spp. the abundances in 1995 and 1999 are significantly different from those in 1996, 1997 and 1998. For both Neomysis americana and Crangon septemspinosa, however, there were fewer instances of statistically significant interannual differences in abundance, and no clear, consistent pattern between years (Table 3).

The broad scale horizontal distributions of Salpa spp. and Phronima spp. were similar. Both species begin to show up in April 1995 in the Northeast Channel (data not shown), with the abundance of salps being much higher than that of the phronimids. By May the majority of organisms were found on the Southern Flank, and then slightly off-bank in June (Figure 3a). In April 1999 Phronima spp. began to appear in high numbers in the Northeast Channel, but there was a much lower number of salps at that time. The numbers of both taxa increased in the Northeast Channel in May along with high abundances on the Southern Flank, and persisted on the Southern Flank in June1999 (Figure 3b). Broad scale horizontal distributions for 1996, 1997 and 1998 are not shown due to the virtual absence of these organisms in those years. In contrast, Neomysis americana and Crangon Septemspinosa were always concentrated inside the $100 \mathrm{~m}$ isobath, and often inside the $60 \mathrm{~m}$ isobath. This broadscale distribution pattern was similar during all years and seasons, although only May and June of 1995 and April, May and June of 1999 are shown (Figure 3c and 3d), for ease of comparison with Salpa spp. and Phronima spp. distributions (Figure 3 a and 3b).

Intrusions of warm water into the Georges Bank region can be seen in AVHRR imagery (Figure 4). Images from the middle of May, 1995-1999, show the interannual variation in sea surface temperatures on Georges Bank. In 1995 and 1999 warm water 
$\left(\geq 16^{\circ} \mathrm{C}\right)$ can be seen intruding inside the $200 \mathrm{~m}$ isobath on the southern flank of Georges Bank, while no such intrusions are seen in 1996, 1997 or 1998. The abundances of Salpa spp., Phronima spp., Neomysis americana and Crangon septemspinosa inside the $200 \mathrm{~m}$ isobath were compared to the percent of warm water within the $200 \mathrm{~m}$ isobath of Georges Bank (Figure 5). Although we sampled on 30 dates, only 19 and 20 sampling dates yielded nonzero data for Salpa spp. and Phronima spp., respectively. Using only the non-zero data, the abundance of Salpa spp. is significantly correlated to the percent cover of warm water on the bank $(\mathrm{r}=0.787, \mathrm{P}<0.001)$. When we consider all 20 non-zero data points for the abundance of Phronima spp., there is a significant correlation with percent warm water cover $(\mathrm{r}=0.621$, $\mathrm{P}<0.001)$. In contrast to Salpa spp. and Phronima spp., there was no significant relationship between percent cover of warm water on the bank and abundance of Neomysis americana ( $\mathrm{r}=$ 0.057, $\mathrm{P}=0.77)$ or Crangon septemspinosa $(\mathrm{r}=-0.167, \mathrm{P}=0.38)$ (Figure 5).

This interannual variability in slope water intrusions can also be seen in the MOC10 CTD data plotted from Standard Station 3 (40.53 N Lat, -68.99 W Long) on the southern flank of Georges Bank for May of each year, 1995 - 1999 (Figure 6). The temperature profiles show two warm water intrusions, one in 1995 and another in 1999. The 1995 profile shows a deep warm water intrusion, while the 1999 profile shows an intrusion that can be seen throughout the entire water column.

The presence of all four taxa was plotted in T-S space, including the delineation of three different water masses (Figure 7). Both Salpa spp. and Phronima spp. showed highly statistically significant different patterns of presence/absence between water masses (Phronima spp.: $\mathrm{X}^{2}=107.010, \mathrm{P}<0.001$; Salpa spp.: $\mathrm{X}^{2}=60.946, \mathrm{P}<0.001$ ), being found predominantly in the Upper Slope/Gulf Stream Water and Georges Bank/Gulf of Maine 
Water. In contrast, Neomysis americana and Crangon septemspinosa were almost exclusively associated with Georges Bank/Gulf of Maine water (N.americana: $\mathrm{X}^{2}=14.154, \mathrm{P}<0.01 ; C$. septempsinosa: $\left.\mathrm{X}^{2}=8.334, \mathrm{P}<0.05\right)$.

\section{Discussion}

Advection of water and biota on and off Georges Bank can be caused by entrainment/detrainment events along the periphery of rotating warm-core rings as they pass the bank, as well as by slope water crossovers onto the bank. The effects of these types of events on phytoplankton and larval fish have been previously studied. For instance, Flierl and Davis (1993) showed that these events can cause upwelling that significantly impacts phytoplankton populations. Flierl and Wroblewski (1985) and Wroblewski and Cheney (1984) showed that entrainment events associated with warm core rings can advect larval fish off the bank and advect warm water fish onto the bank. The question then is how do these events affect the macrozooplankton and micronekton of the Georges Bank region? Here a brief review of the life histories of our four taxa of interest is relevant.

Salps can be an abundant and important component of pelagic ecosystems (Andersen, 1998). As a result of their asexual reproduction, their population growth rate is one of the fastest among multicellular animals (Andersen and Nival, 1986; Madin and Deibel, 1988), which in turn can lead to rapid blooms (e.g. Menard et al., 1994). Phronima is a circumglobal genus that inhabits the tropical water of the world's oceans. Although Vinogradov et al. (1996) state that Phronima only very rarely cross the limits of the subtropical convergences, Madin (pers. comm.) states that $P$. sedentaria and $P$. atlantica are common in the slope water south of Georges Bank. Phronima have an unusual and 
interesting symbiotic relationship with Salpa. Both male and female Phronima make a "barrel" out of the body of a salp by eating away the internal organs and leaving a barrelshaped portion of the non-cellular salp test. Both sexes occupy these barrels, although it is more common for females, which keep their brood of young within the barrel until they are developed enough to swim and survive independently (Davenport, 1994). This barrelmaking behavior appears to be an obligate relationship for Phronima, although salps are not the sole source of the barrels. Phronima also prey upon pyrosomes and siphonophores (Laval, 1978). Thus Salpa spp. and Phronima spp. would be expected to co-occur, especially in the slope waters south of Georges Bank.

Neomysis americana is the most common marine mysid in the shallow coastal waters of the Northwest Atlantic Ocean (Wigley and Burns, 1971; Williams et al, 1974; Hoffmeyer, 1990). In the Georges Bank region it is most commonly reported inside the $60 \mathrm{~m}$ isobath and was not found outside the $100 \mathrm{~m}$ isobath (Whiteley, 1948). N. americana is a euryhaline species (Pezzack and Corey, 1982) and is found in water temperatures from $0->25^{\circ} \mathrm{C}$ (Wigley and Burns, 1971). The decapod shrimp Crangon septemspinosa is common in estuaries in the Northwest Atlantic and is found from the Gulf of St. Lawrence to Florida (Haefner, 1979). Adults leave the estuarine shallows when the water temperature drops below $20^{\circ} \mathrm{C}$ and move to deeper water, but return when the water warms (Corey, 1981, Modlin, 1980). C. septemspinosa are found in water temperatures ranging from $3-25^{\circ} \mathrm{C}$ and are effective osmoregulators able to tolerate salinities up to 36 for males and 39 for females (Haefner, 1969a,b). Whiteley (1948) reported an extended spring spawn of C. septemspinosa on Georges Bank, but rarely observed individuals outside the $100 \mathrm{~m}$ isobath. 
During our sampling on Georges Bank the presence of Salpa spp. and Phronima spp. was a conspicuous biological correlate of the slope water intrusions in 1995 and 1999, and contrasted with their total absence in 1996-1998. It may also be contrasted with the presence of the two other macrozooplanktonic species, the mysid Neomysis americana and the decapod shrimp Crangon septemspinosa. Both these species occurred typically within the $100 \mathrm{~m}$ isobath of Georges Bank, and although there were interannual variations in their abundances, there was no correlation with warm water intrusions (Figure 5). More generally though, warm core rings are known to contain distinct assemblages of macrozooplankton and micronekton that are transported along with the water mass (Wiebe et al., 1985a; Young, 1989).

The distribution of Salpa spp. and Phronima spp. within T-S space showed significant differences between the three defined water regimes (Figure 7). The broad distribution of the two taxa across the different water regimes was somewhat surprising, as we expected that these taxa would be found predominantly in the Upper Slope/Gulf Stream Water (USW). They were found almost as often in Georges Bank/Gulf of Maine Water (GBW) as in USW, but seldom in the Scotian Shelf Water (SSW). Their presence in GBW can be seen as an indication of the extent of mixing of these species during the warm water intrusion events. In fact, 51.6 and $49.4 \%$ of the occurrences of Salpa spp. and Phronima spp., respectively, in GBW occurred in May or June of 1995 or 1999, periods during which warm core rings occurred and these organisms were presumably mixed from USW to GBW. That is, if organisms move between two different water masses that are moving in different directions or at different speeds, this would increase their dispersion. In this way vertical migration of Phronima between USW and GBW in May of 1995 (data not shown) may be 
an additional source of (active) mixing. Our finding that Neomysis americana and Crangon septemspinosa were almost exclusively associated with Georges Bank/Gulf of Maine water is consistent with the more qualitative observations of Whiteley (1948). Both N. americana and C. septemspinosa may use bottom-dwelling as a strategy to avoid displacement when flows become strong (Lawrie et al., 1999) or when temperatures increase (Jeffery and Revill, 2002), such as would be the case with warm water intrusions.

In addition to these direct effects on distribution and abundance, warm water intrusions may affect Salpa spp. and Phronima spp. in more indirect and subtle ways related to their association or symbiosis. Previous studies on the relationship between salps and phronimids have primarily focused only on the use of the salp barrel by the phronimid, with little else said about their co-occurrence or life history dynamics. Sardou et al. (1996) did point out that Phronima sedentaria showed a maximum abundance when Salpa fusiformes were also abundant, namely the spring, in the Mediterranean Sea. Because salps are part of the phronimid diet and the barrels are used for protection and rearing of the offspring, the phronimids are reliant on the salps at certain points of their life cycle. It is important to note, however, that the relationship between these two species is not obligatory. Moreover, Phronima spp. do not need these barrels throughout their entire life cycle. Most of the phronimids in our samples were found without a barrel, although it is possible that they were dislodged from the barrels during sampling.

Looking at the horizontal broad-scale distribution of Salpa spp. and Phronima spp. on Georges Bank in May and June of 1995 and 1999, considerable overlap is evident, but there are also a few locations where salps are abundant and the phronimids are completely absent (Figure 3). Because of the ability of salps to reproduce quickly and produce blooms 
(Andersen and Nival, 1986, Madin and Deibel, 1988, Menard et al., 1994), it is not surprising that their abundance is at times much higher than that of the Phronima spp.

In summary, we found striking seasonal and interannual variability in the abundance of Salpa spp. and Phronima spp. on Georges Bank. The broad scale distribution of Salpa spp. and Phronima spp. was positively linked to slope water intrusions, as determined by both satellite derived sea surface temperature and subsurface hydrography. This was not the case for Neomysis americana and Crangon septemspinosa, whose abundance on the bank was much less variable, especially inside the $60 \mathrm{~m}$ isobath, and seemed not to be affected to any significant degree by slope water instrusions. Thus warm water intrusions can directly affect some macrozooplankton (e.g., Salpa spp. and Phronima spp.) by advecting them onto the bank, and may also have indirect effects as a consequence of trophic interactions (e.g., salps have high filtration rates on phytoplankton (Madin, 1974) and can be a source of food for fishes such as cod and tuna (Silver, 1975)), although this was beyond the scope of the present study. Other taxa (e.g., Neomysis americana and Crangon septemspinosa) that are resident on the bank seem little affected by warm water intrusions. The overall consequence of these intrusion events on the Georges Bank food web remains to be determined, but can be expected to vary between species. 


\section{Literature Cited}

Andersen, V. (1998) Salp and pyrosomid blooms and their importance in biogeochemical cycles. In: Bone Q (ed.) The biology of pelagic tunicates. Oxford University Press, Oxford pp. 125-138.

Andersen, V. and Nival, P. (1986) A model of the population dynamics of salps in coastal waters of the Ligurian Sea. J. Plankton Res., 8, 1091-1110.

Ashjian, C.J., Davis, C.S., Gallagher, S.M. and Alatalo, P. (2001) Distribution of plankton, particles, and hydrographic features across Georges Bank described using the Video Plankton Recorder. Deep Sea Res. II, 48, 245-282.

Backus, R.H. and Bourne, D.A. (eds.) (1987) Georges Bank. MIT Press, Cambridge, MA.

Bigelow, H.B. (1926) Plankton of the offshore waters of the Gulf of Maine. Bull. US Bur. Fish., 40, 1-509.

Bowman, T.E. and Gruner, H.-E. (1973) The Families and Genera of Hyperiidea (Crustacea: Amphipoda). Smithsonian Institution Press, Washington, DC.

Butman, B. and Beardsley. R.C. (1987) Physical Oceanography. In: Backus, R.H. and Bourne, D.A. (eds.) Georges Bank. MIT Press, Cambridge, MA, pp. 88-98.

Cohen, E.B. and Grosslein, M.D. (1987) Production on Georges Bank compared with other shelf ecosystems. In: Backus, R.H. and Bourne, D.A. (eds.) Georges Bank. MIT Press, Cambridge, MA, pp. 383-391.

Corey, S. (1987) Reproductive strategies and comparative fecundity of Crangon septemspinosa Say (Decapoda, Caridea), Crustaceana, 52, 25-28.

Cornillon, P., Lee, T. and Fall, G. (1994) On the probability that a Gulf Stream 
meander crest detaches to form a warm core ring. J. Phys. Oceanogr., 24, $159-171$.

Davenport, J. (1994) Observations on the locomotion and buoyancy of Phronima sedentaria (Forskal, 1775) (Crustacea: Amphipoda: Hyperiidea). J. Nat. Hist., 28, 787793.

Flagg, C.N. (1987) Hydrographic structure and variability. In: Backus, R.H. and Bourne, D.A. (eds.) Georges Bank. MIT Press, Cambridge, MA, pp. 108-124.

Flierl, G.R. and Davis, C.S. (1993) Biological effects of Gulf Stream meandering. J. Mar. Res., 51, 529-560.

Flierl, G.R. and Wroblewski, J.S. (1985) The possible influence of warm core Gulf Stream rings upon shelf water larval fish distribution. Fish. Bull., 83, 313-330.

GLOBEC (1992) Northwest Atlantic Implementation Plan. US Global Ocean Ecosystems Dynamics Report Number 6.

Gosner, K.L. (1971) Guide to Identification of Marine and Estuarine Invertebrates: Cape Hatteras to the Bay of Fundy. Wiley-Interscience, New York.

Haefner, P.A. (1969a) Temperature and salinity tolerance of the sand shrimp Crangon septemspinosa Say. Physiol Zool. 42, 388-397.

Haefner, P.A. (1969b) Osmoregulation of Crangon septemspinosa Say (Crustacea: Caridae). Biol Bull. 42, 438-446.

Hoffmeyer, M.S. (1990) The occurrence of Neomysis americana in two new localities of the South American Coast (Mysidacea). Crustaceana 58, 186-192.

Jeffery, S. and Revill, A. (2002) The vertical distribution of southern North Sea Crangon crangon (brown shrimp) in relation to towed fishing gears as 
influenced by water temperature. Fish. Res. 55, 319 - 323.Laval, P. (1978) The barrel of the pelagic amphipod Phronima sedentaria (Forsk.) (Crustacea: Hyperiidea). J. Exp. Mar. Biol. Ecol., 33, 187-211.

Lawrie, S.M., Speirs, D.C., Rafaelli, D.G., Gurney, W.S.C., Paterson, D.M., and Ford, R. (1999) The swimming behavior and distribution of Neomysis integer in relation to tidal flow. J. Exp. Mar. Biol. Ecol. 242, 95 - 106.

Limeburner, R. and Beardsley, R.C. (1996) Near surface recirculation over Georges Bank. Deep Sea Res. II, 43, 1547-1574.

Madin, L.P. (1974) Field observations on the feeding behavior of salps (Tunicata: Thaliacea). Mar. Biol., 25, 143-147.

Madin, L.P. and Deibel, D. (1998) Feeding and energetics of Thaliacea. In: Bone Q (ed.) The biology of pelagic tunicates. Oxford University Press, Oxford pp. 81-104.

Menard, F., Dallot, S., Thomas, G. and Braconnot, J.-C. (1994) Temporary fluctuations of two Mediterranean salp populations from 1967 to 1990. Analysis of the influence of environmental variables using a Markov chain model. Mar. Ecol. Prog. Ser., 104, 139-152.

Modlin, R.F. (1980) The life cycle and recruitment of the sand shrimp, Crangon septemspinosa, in the Mystic River Estuary, Connecticut, Estuaries, 3, 1-10.

Pezzack, D.S. and Corey, S. (1979) The life history and distribution of Neomysis americana (Smith) (Crustacea: Mysidacea) in Passamaquoddy Bay. Can J Zool, 57, 785-793.

Ramp, S.R., Schlitz, R. and Wright, W.R. (1985) On the deep transport of mass, heat and nutrients through northeast channel, Gulf of Maine. J. Phys. 
Oceanogr., 15, 1790-1808.

Ryan, J.P., Yoder, J.A. and Townsend, D.A. (2001) Influence of a Gulf Stream warm-core ring on water mass and chlorophyll distributions along the southern flank of Georges Bank. Deep Sea Res. II, 48, 159-178.

Sardou, J., Etienne, M. and Andersen, V. (1996) Seasonal abundance and vertical distributions or macroplankton and micronekton in the Northwest Mediterranean Sea. Oceanol. Acta, 19, 645-656.

Shih, C. (1969) The systematics and biology of the family Phronimidae (Crustacea: Amphipoda). Dana Report No. 74.

Silver, M.W. (1975) The habitat of Salpa fusiformis in the California Current as defined by indicator assemblages. Limnol. Oceanogr., 20, 230-237.

Tattersall, W.M., Tattersall, O.S. (1951) The British Mysidacea. The Ray Society, London

Vinogradov, M.E., Volkov, A.F. and Demenova, T.N. (1996) Hyperid Amphipods (Amphipoda, Hyperiidea) of the World Oceans. Science Publishers, Lebanon, NH. Whitely,G.C. Jr. (1948) The distribution of larger planktonic crustacea on Georges Bank, Ecol. Monogr. 18, 233-264.

Wiebe, P.H., Flierl, G.R., Davis, C.S., Barber, V. and Boyd. S.H. (1985a) Macrozooplankton biomass in Gulf Stream warm-core rings: spatial distribution and temporal changes. J. Geophys. Res., 90, 8885-8901.

Wiebe, P.H., Morton, A.W., Bradley, A.M., Backus, R.H., Craddock, J.E., Barber, V., Cowles, T.J. and Flierl, G.R. (1985b) New developments in the MOCNESS, an apparatus for sampling zooplankton and micronekton. Mar. 
Biol., 85, 313-323.

Wigley, R.L. and Burns, B.R. (1971) Distribution and biology of mysids (Crustacea, Mysidacea) from the Atlantic coast of the United States in the NMFS Woods Hole Collection. US Fish Wildlife Serv Fish Bull. 69, 717-746.

Williams, A.B. (1984) Shrimps, Lobsters, and Crabs of the Atlantic Coast of the eastern United States, Maine to Florida. Smithsonian Institution Press, Washington, DC

Williams, A.B., Bowman, T.E., Damkaer, M.N. (1974) Distribution, variation, and supplemental description of the opossum shrimp, Neomysis americana (Crustacea: Mysidacea). US Fish Wildlife Serv Fish Bull 72, 835-842

Wroblewski, J.S. and Cheney, J. (1984) Ichthyoplankton associated with a warm core ring off the Scotian Shelf. Can. J. Fish. Aquat. Sci., 41, 294-303.

Young, J.W. (1989) The distribution of hyperiid amphipods (Crustacea: Pericarida) in relation to warm-core eddy $\mathrm{J}$ in the Tasman Sea. J. Plankton Res., 11, 711-728. 


\begin{tabular}{|l|l|}
\hline \multicolumn{1}{|c|}{ Dates of Cruise } & \multicolumn{1}{|c|}{$\begin{array}{c}\text { Number of } \\
\text { Stations Sampled }\end{array}$} \\
\hline February 10-20,1995 & 5 \\
\hline March 13-24, 1995 & 3 \\
\hline April 11-22, 1995 & 6 \\
\hline May 9-18, 1995 & 16 \\
\hline June 5-15, 1995 & 23 \\
\hline July 10-20, 1995 & 27 \\
\hline January 10-22, 1996 & 2 \\
\hline February 13-25, 1996 & 9 \\
\hline March 11-22, 1996 & 12 \\
\hline April 8-20, 1996 & 5 \\
\hline May 6-17, 1996 & 12 \\
\hline June 3-13, 1996 & 38 \\
\hline January 13-20,1997 & 8 \\
\hline February 11-23, 1997 & 8 \\
\hline March 16-28, 1997 & 13 \\
\hline April 22-May 2, 1997 & 14 \\
\hline May 19-27, 1997 & 20 \\
\hline June 18-28, 1997 & 32 \\
\hline January 7-19, 1998 & 16 \\
\hline February 7-17, 1998 & 13 \\
\hline March 15-27, 1998 & 13 \\
\hline April 15-27,1998 & 20 \\
\hline May 11-23, 1998 & 21 \\
\hline June 16-26, 1998 & 32 \\
\hline January 11-24, 1999 & 15 \\
\hline February 11-23, 1999 & 11 \\
\hline March 10-23, 1999 & 1 \\
\hline April 16-28, 1999 & 19 \\
\hline May 19-27, 1999 & 19 \\
\hline June 14-24, 1999 & 32 \\
\hline & \\
\hline
\end{tabular}

Table 1. Dates of GLOBEC Broad-Scale Survey Cruises with number of stations sampled with the MOC10. 


\begin{tabular}{|c|c|c|c|c|}
\hline Species & $\begin{array}{c}\text { Mean } \\
\text { TWC } \\
\text { abundance }\end{array}$ & Standard Error & $\begin{array}{c}\text { Maximum } \\
\text { abundance } \\
\text { found }\end{array}$ & $\begin{array}{c}\text { Month of } \\
\text { maximum } \\
\text { abundance }\end{array}$ \\
\hline $\begin{array}{c}\text { Salpa } \\
\text { spp. }\end{array}$ & 21.61 & 14.08 & $6,406.18$ & June 1999 \\
\hline Phronima spp. & 0.87 & 0.22 & 56.99 & May 1995 \\
\hline $\begin{array}{c}\text { Crangon } \\
\text { septemspinosa }\end{array}$ & 5.69 & 1.15 & 313.98 & May 1998 \\
\hline $\begin{array}{c}\text { Neomysis } \\
\text { americana }\end{array}$ & 93.83 & 67.15 & $30,547.97$ & May 1996 \\
\hline
\end{tabular}

Table 2. Mean total water column (TWC) abundances $\left(\# / 1,000 \mathrm{~m}^{3}\right)$, standard error of the mean, and the maximum TWC abundances (with corresponding month) for Salpa spp., Phronima spp, Crangon septemspinosa, and Neomysis americana. 


\begin{tabular}{|l|l|l|l|l|}
\hline \multicolumn{5}{|c|}{ Salpa spp. } \\
\hline & 1995 & 1996 & 1997 & 1998 \\
\hline 1996 & $* *$ & \multicolumn{3}{|c|}{} \\
\hline 1997 & $* *$ & & \multicolumn{1}{|c|}{} \\
\hline 1998 & $* *$ & & & \\
\hline 1999 & & $* *$ & $* *$ & $* *$ \\
\hline
\end{tabular}

\begin{tabular}{|l|l|l|l|l|}
\hline \multicolumn{5}{|c|}{ Phronima spp. } \\
\hline & 1995 & 1996 & 1997 & 1998 \\
\hline 1996 & $* *$ & \multicolumn{3}{|c}{} \\
\hline 1997 & $* *$ & & \multicolumn{1}{|l}{} \\
\hline 1998 & $* *$ & & & \\
\hline 1999 & & $* *$ & $* *$ & $* *$ \\
\hline
\end{tabular}

\begin{tabular}{|l|l|l|l|l|}
\hline \multicolumn{6}{|c|}{ Crangon septemspinosa } \\
\hline & 1995 & 1996 & 1997 & 1998 \\
\hline 1996 & & \multicolumn{3}{|c|}{} \\
\hline 1997 & $* *$ & & \multicolumn{2}{|c|}{} \\
\hline 1998 & $*$ & & & \\
\hline 1999 & $*$ & & & \\
\hline
\end{tabular}

\begin{tabular}{|l|l|l|l|l|}
\hline \multicolumn{5}{|c|}{ Neomysis americana } \\
\hline & 1995 & 1996 & 1997 & 1998 \\
\hline 1996 & & \multicolumn{3}{|c|}{} \\
\hline 1997 & $*$ & & \multicolumn{2}{|l|}{} \\
\hline 1998 & & & * & \\
\hline 1999 & & $*$ & $* *$ & \\
\hline
\end{tabular}

Table 3. Results of the Mann-Whitney U-tests with Bonferroni Adjustment on the interannual differences in abundances. (Significance levels, ${ }^{*} \mathrm{P} \leq 0.05,{ }^{*} \mathrm{P} \leq 0.01$ ) 


\section{Figure Captions}

Figure 1. Cruise Track and station locations (filled dots) for the Georges Bank GLOBEC Broad Scale Surveys (1995-1999), including bathymetry $(60,100,200 \mathrm{~m})$ and regions of note.

Figure 2. Log-transformed abundance $\left[\left(\left(\# / 1000 \mathrm{~m}^{3}\right)+1\right)\right.$ mean $\left.\pm \mathrm{SE}\right]$ of Salpa spp. and Phronima spp., Crangon septimspinosa, and Neomysis americana on Georges Bank (1995-1999).

Figure 3. Broad scale horizontal distributions of Salpa spp. and Phronima spp., Crangon septimspinosa, and Neomysis americana using log-transformed water column total abundances

[(\#/1000m3) + 1] for May and June 1995 and April, May and June of 1999. Distributions of Salpa spp. and Phronima spp. are shown for a) May and June of 1995 and b) April, May and June of 1999. Distributions of Crangon septimspinosa and Neomysis americana are, also, shown for c) May and June of 1995 and d) April, May and June of 1999. Each plot represents data for a single broad scale survey, with vertically stratified samples summed to yield water column total abundance at a given station. Note the different scales for Salpa spp. and Phronima spp.

Figure 4. Satellite-derived sea surface temperature images from May $1995-1999$. The images for 1995-1998 are 3-day optimally interpolated images. The 1999 image is not optimally interpolated, as that image was not yet available. The white ovals point out the 
location of Standard Station 3, where the temperature profiles used in Figure 6 were obtained.

Figure 5. Scatter plot of the log transformed abundance data for Salpa spp. and Phronima spp. inside the $200 \mathrm{~m}$ isobath versus the percent cover of warm water within the $200 \mathrm{~m}$ isobath of the Georges Bank region, 1995-1999. Bracket indicates outlier data point removed in test for correlation.

Figure 6. Temperature profiles from Standard Station 3 (40.53 N Lat, -68.99 W Long) on the southern flank of Georges Bank from May 1995, 1996 (representative of a non-intrusion year) and 1999. The lines are $3 \mathrm{~m}$ averaged MOC10 CTD data. The profiles show the warm water intrusions of 1995 and 1999, with the 1995 intrusion being deeper and the 1999 intrusion being seen throughout the entire water column.

Figure 7. Presence of Salpa spp. and Phronima spp., Crangon septemspinosa and Neomysis americana in T-S space. The boxes indicate the three water masses - Scotian Shelf Water (SSW), Georges Bank/Gulf of Maine Water (GBW), and Upper Slope/Gulf Stream Water (USW) from Flagg (1987). Solid symbols indicate samples taken during May and June of 1995 and 1999. Differences between water masses in the presence/absence of each species were tested using chi-square distribution $\left({ }^{* *}=\mathrm{P} \leq 0.01,{ }^{*}=\mathrm{P} \leq 0.05\right)$. 


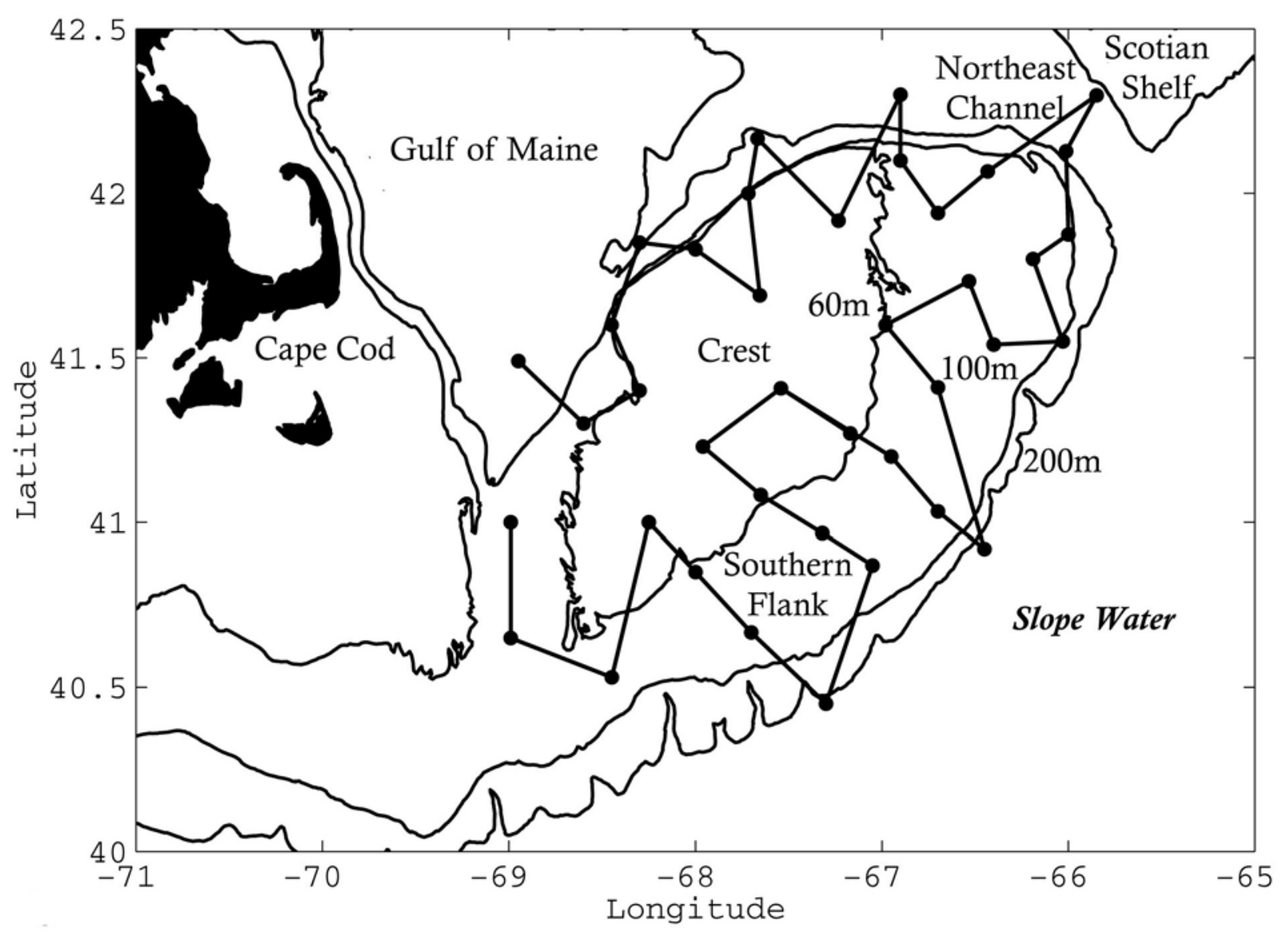

Figure 1 


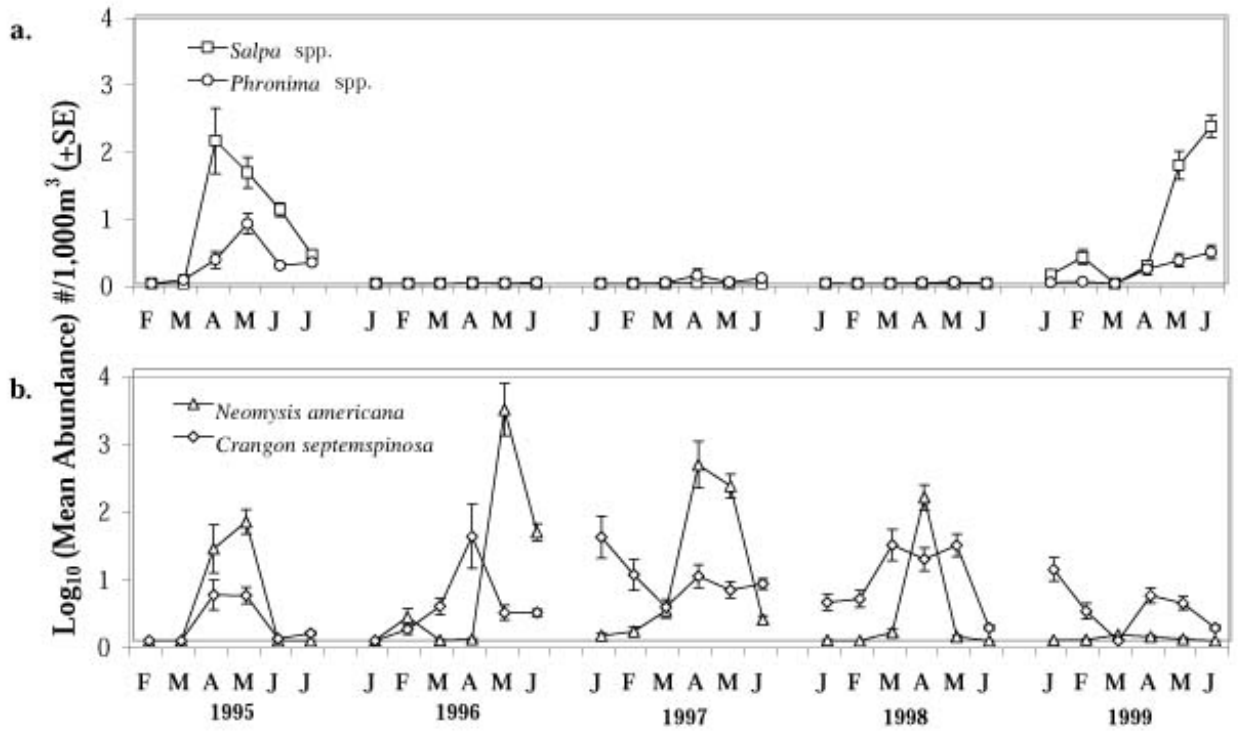

Figure 2 

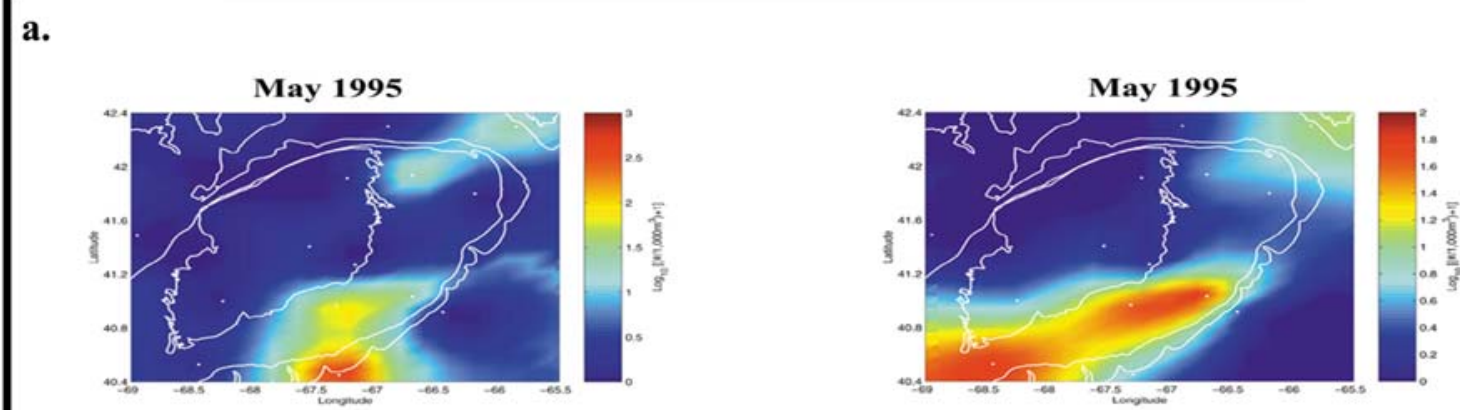

June 1995

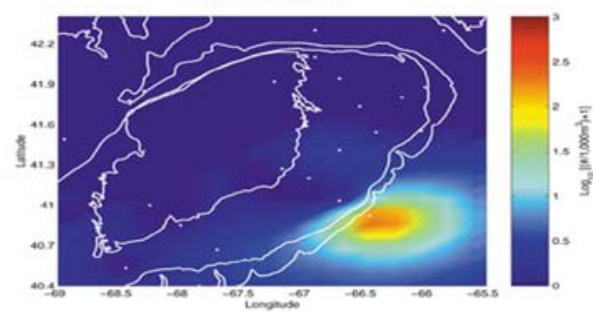

June 1995

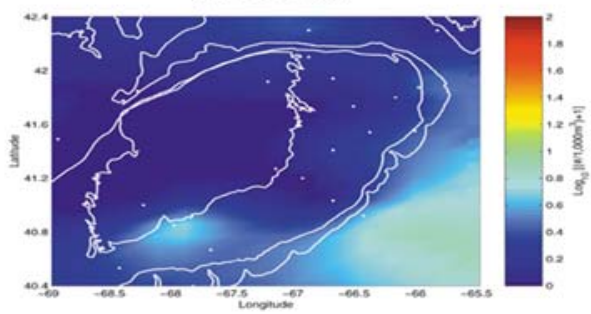

b.
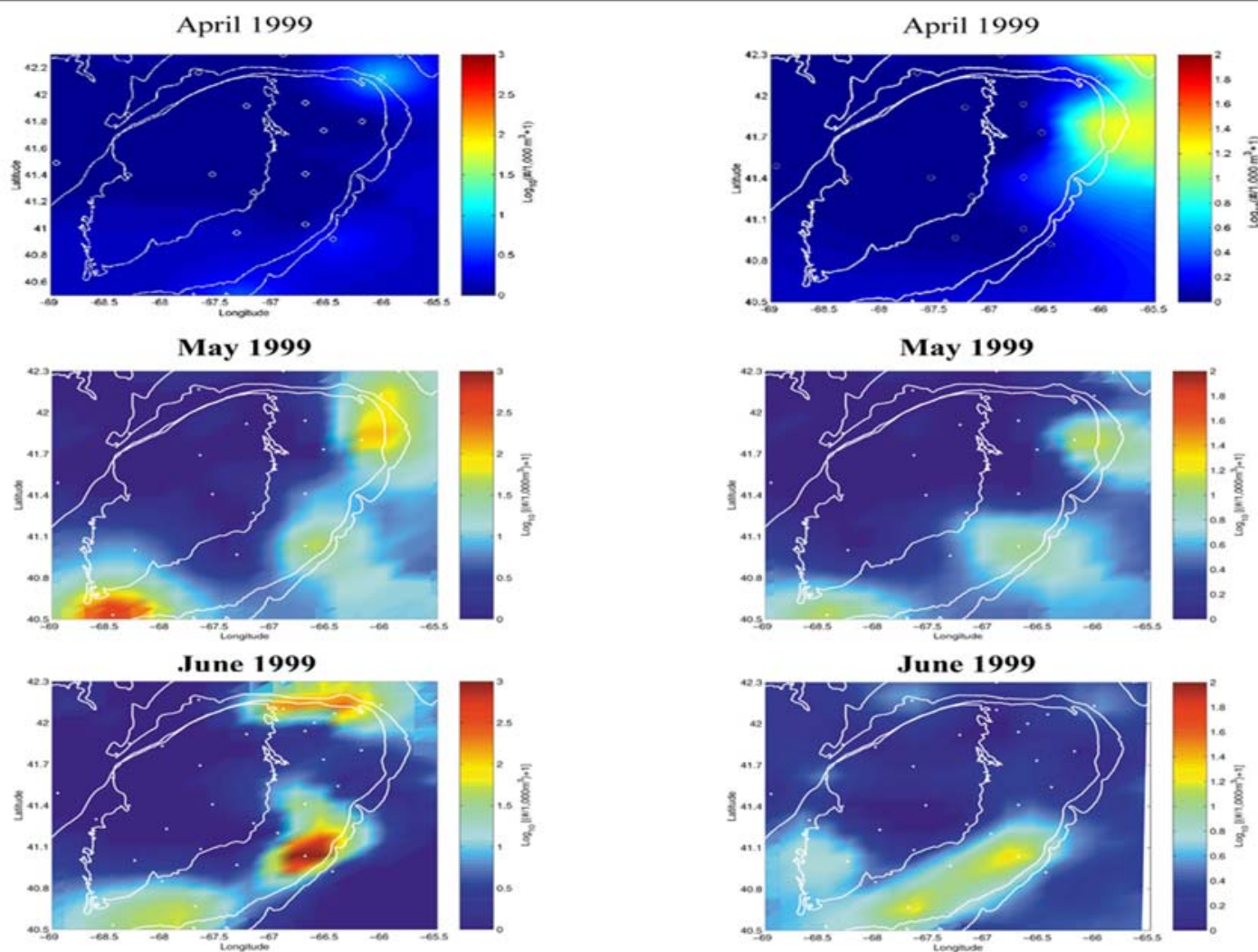

Figure 3 


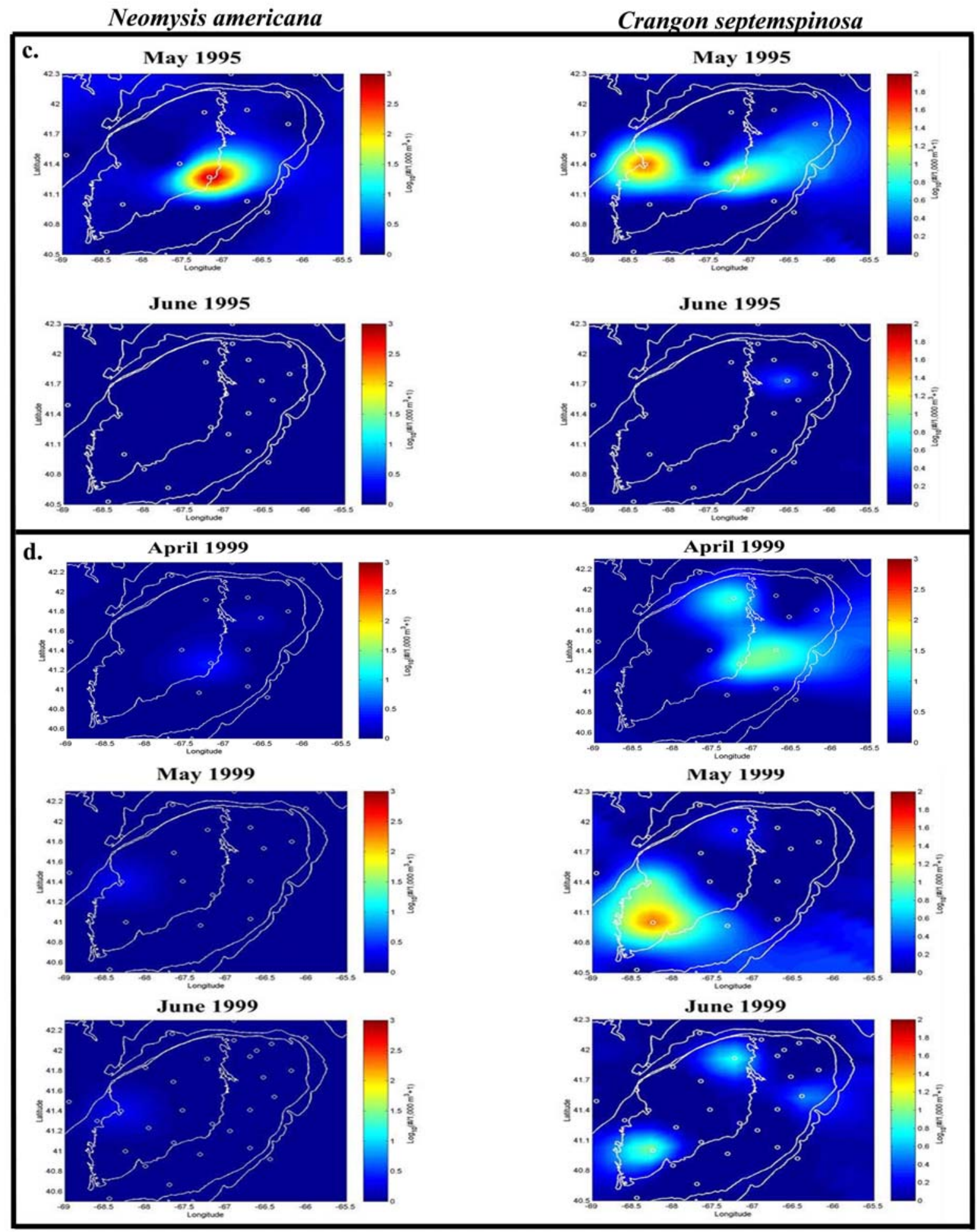

Figure 3 continued 
1995

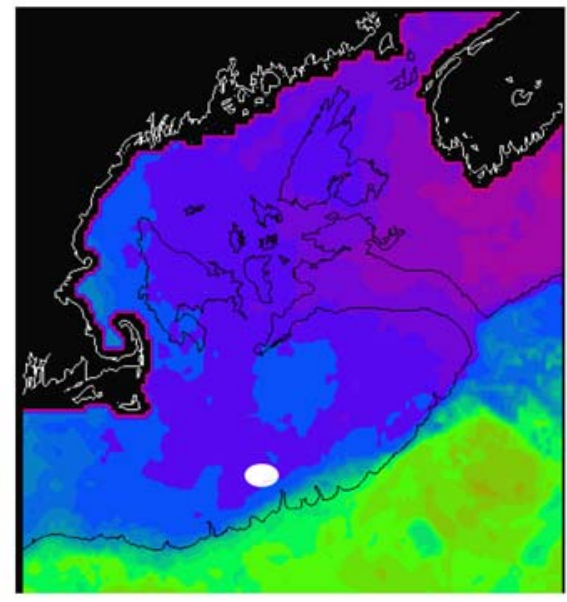

1997

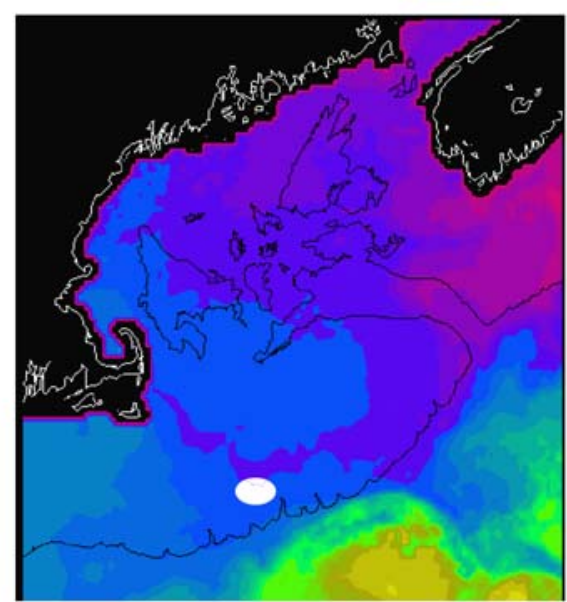

1996

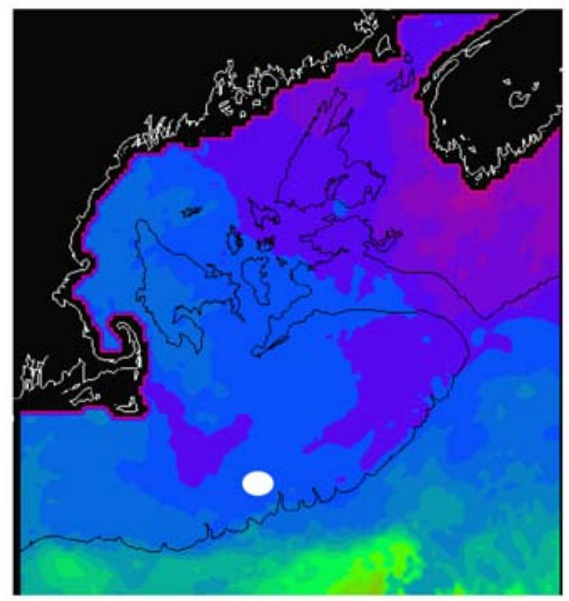

1998

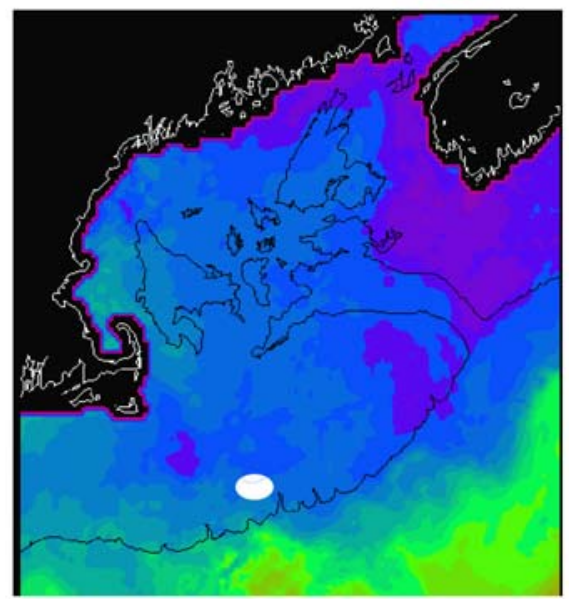

1999

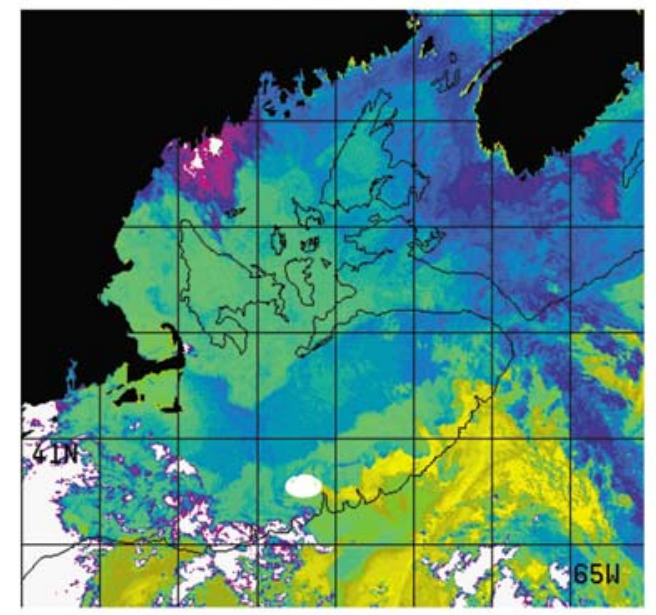

Figure 4 

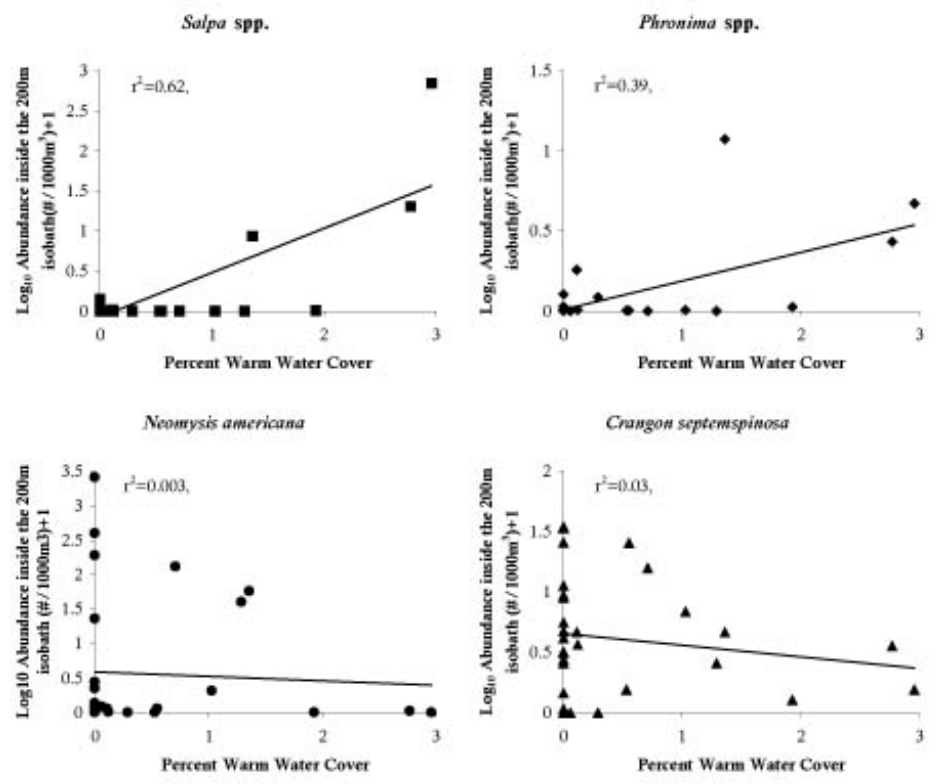

Figure 5 


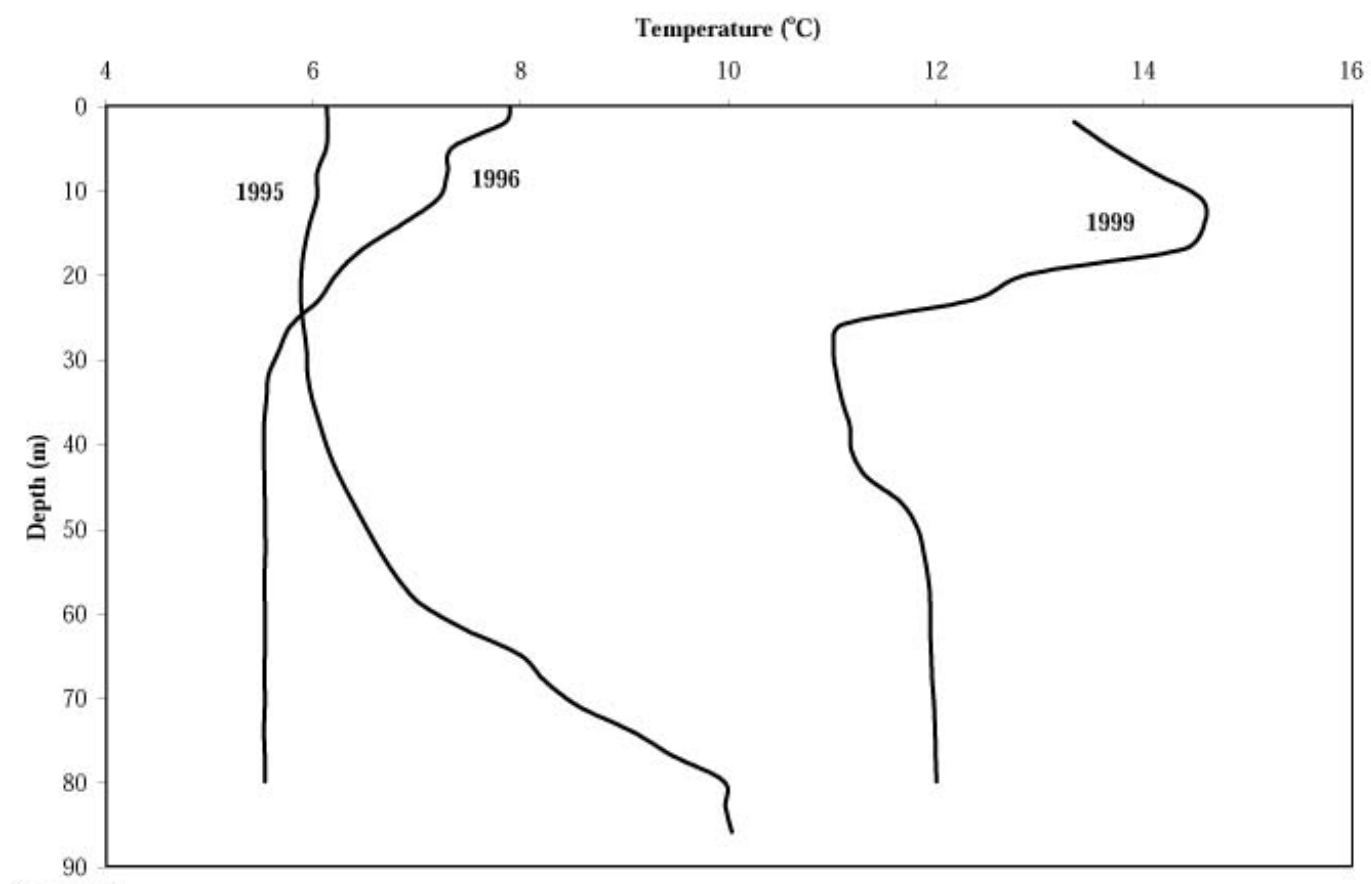

Figure 6 


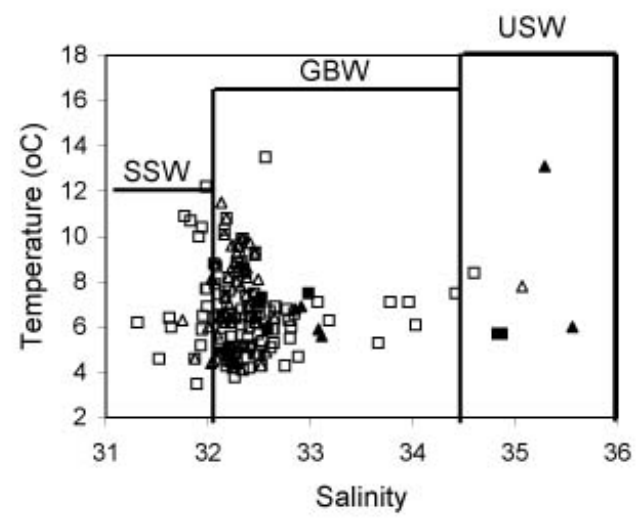

口 Crangon septemspinosa * $\Delta$ Neomysis americana **

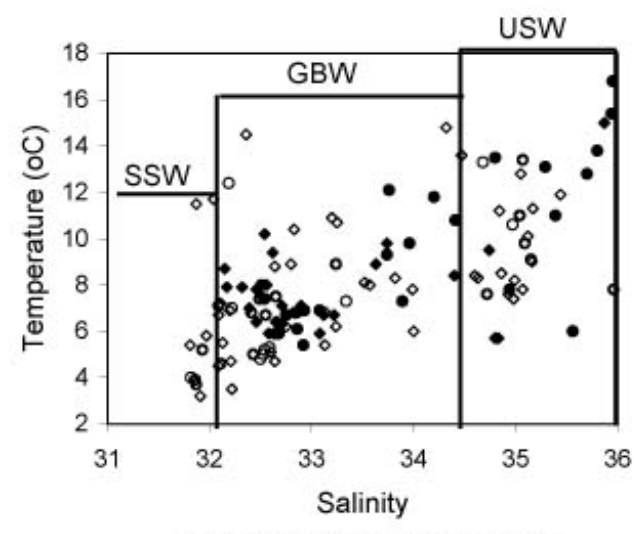

○ Salpa spp. ** ० Phronima spp. **

Figure 7 


\section{Acknowledgements}

We would like to thank Gretchen Stoltz, Darren Gewant, Heidi Franklin and Mari Butler for their assistance with sample analysis. We would also like to thank Glenn Strout and Jim Bisagni for making the satellite data available and Toby Garfield for his generous help in the analysis of the AVHRR data and help with MATLAB. A great deal of thanks goes to the scientists and crews of the Albatross IV, Endeavor, and Oceanus for their hard work and long hours put in collecting samples on the broad-scale cruises. Additional thanks goes to Tom Niesen and Stan Williams for their advice on data analysis and interpretation. This work was supported by NSF award No. OCE96-17209 and NOAA award No. NA66GP0356 to S. M. Bollens provided from the US GLOBEC Northwest Atlantic/Georges Bank Program, a joint program of the National Science Foundation and the National Oceanic and Atmospheric Administration. This is contribution number __ of the US GLOBEC Northwest Atlantic/Georges Bank Program. 